\title{
Constructing Image: The Self-Praise Strategies on Corporate Social Responsibility Reports
}

\author{
Xiaojun Wu, Lixia Chen \\ School of Humanities and Social Science, Xi'an Polytechnic University, Xi'an, China \\ Email: kelseyngngng@gmail.com
}

How to cite this paper: Wu, X. J., \& Chen, L. X. (2021). Constructing Image: The SelfPraise Strategies on Corporate Social Responsibility Reports. Open Journal of Modern Linguistics, 11, 672-687.

https://doi.org/10.4236/ojml.2021.114053

Received: August 3, 2021

Accepted: August 22, 2021

Published: August 25, 2021

Copyright $\odot 2021$ by author(s) and Scientific Research Publishing Inc. This work is licensed under the Creative Commons Attribution International License (CC BY 4.0).

http://creativecommons.org/licenses/by/4.0/

\begin{abstract}
This study explores self-praise strategies utilized in Telstra CSRRs from 2016 to 2020 with a view of how these self-praising strategies contribute to Telstra images construction. The self-praise categories and the frequency of each selfpraise category are analyzed. It is found that the indirect self-praise strategies are more frequently utilized than the direct self-praise strategies in Telstra CSRRs. In addition, through direct self-praise strategies, Telstra CSRRs construct Telstra as a responsive, pioneering and highly influential company in Australia while they depict Telstra as a caring, concerned about interest of society and employees, responsible enterprise via indirect self-praise strategies. This study provides some insight into self-praise in organizational settings as well as the construction of corporate image exhibited in CSRRs.
\end{abstract}

\section{Keywords}

Self-Praise, Corporate Image, Corporate Social Responsibility Report

\section{Introduction}

Over the past few decades, the public have been showing an increasing awareness of human activities on social and environmental issues in general, enterprises actions in particular (Ditlev-Simonsen, 2010). There is a growing public expectation for enterprises to fulfil their social and environmental obligations, modify their business practices to alleviate their adverse effect on social and environmental problems and make a positive contribution to the communities in which they operate (Juholin, 2004). The public, governments and global organizations are making requests for enterprises to act responsibly. As a result, many enterprises are attempting to satisfy these demands with implementing various sustainable business practices. A number of enterprises carry out sustainable projects, 
take preventive measures, develop actionable instructions to make them operate more sustainably.

It also needs to point out that stakeholders not only ask for enterprises to behave responsibly but also to provide various accesses to information about the sustainable efforts that enterprises have made. Such information is vital for stakeholders to keep in touch with enterprises. Growing number of enterprises communicates with stakeholders through different channels such as corporate official websites, social media platforms and advertisements. Increasingly, enterprises are presenting their corporate social responsibility reports (hereafter CSRRs) annually on corporate's official websites. CSRRs are gradually regarded as an enterprise commitment to CSR goals, an access to provide information about enterprise CSR efforts and a tactical presentation of enterprise initiatives (Danuta de Grosbois, 2012). The importance of CSRRs reflects stakeholders' requirement for enterprises to undertake corporate social responsibility and to show concern for public interest. In addition, enterprises embrace corporate social responsibility for strategic intentions to improve their competitive advantage (Lee, 2008). Enterprises can enhance their corporate image, publicize their achievements to the public, and enrich access to the public feedback via CSRRs, which in turn can help enterprises obtain positive public perceptions as well as improve relations with the public in a competitive environment. In the context of making use of CSRRs as a part of the communication process between enterprises and stakeholders, enterprises purposely construct specific images to stakeholders. Such constructed images may have influenced on stakeholders' opinions on the enterprises (Brown, Dacin, Pratt, \& Whetten, 2006). Therefore, CSRRs are the essential channels in boosting the performance of enterprises and enhancing positive corporate image.

From the perspective of politeness theory in linguistics, self-praise is one type of self-promotion (Ren \& Guo, 2020), which is described that people make positive self-description with the aim to build an admirable self-image as well as the desire to make a good impression on others (Tice et al., 1995). Self-praise can be seen as a socially risky activity (Dayter, 2021). It is assumed that self-praise challenges the politeness theory, since it is to some extent considered as a potentially face threatening behavior for the speaker does not care about the hearer's feelings (Brown \& Levinson, 1987). However, self-praising speech act abounds in CSRRs. Therefore, studying self-praises strategies utilized in CSRRs can add to an understanding of self-praising pragmatic strategies in CSRRs as well as shed light on these strategies' role in corporate image construction.

Previous researches on self-praise have mainly focused on the aspect of online social network (Rüdiger \& Dayter, 2020; Ren \& Guo, 2020; Matley, 2018; Tobback, 2019; Guo \& Ren, 2020; Dayter, 2014) and have paid exceptionally less attention to the aspect of CSRRs. However, it is believed that CSRRs play an essential corporate communication role in the process of corporate image construction (Pang et al., 2018). Hence, the present study aims to investigate self-praises 
strategies on CSRRs in an attempt to study corporate image construction, which is still notably under-researched.

This paper aims to explore self-praise strategies utilized in Telstra CSRRs from 2016 to 2020 with a view of how these self-praising strategies contributes to Telstra images construction. In what follows, previous studies on self-praise will be reviewed. Next, the methodology adopted in this paper will be presented. Then the research findings will be discussed in details. In the final section, the conclusions of this paper will be summarized and some hints for further research will be provided.

\section{Literature Review}

\subsection{Self-Praise Studies}

Previous studies on psychology and linguistics indicate that most scholars view self-praise behavior, bragging or boasting about oneself, in social interaction as a potentially problematic act (Pomerantz, 1978; Leech, 1983; Brown \& Levinson, 1987). From the perspective of psychology, Pomerantz (1978) examined compliment responses of an organization that are subjected to separate constraints systems and assumed that self-praise is a series of perceptible and collectible behavior with the likelihood of growing into adverse situations. Following Pomerantz's (1978) study, Speer (2012) showed that a wide range of ways in which direct self-praise behaviors are labelled as well as addressed as troublesome act by both speakers and listeners, which make them become likely to be influenced by accusing statement of boasting and negative attribution. Wu (2011) set up a corpus of China face-to-face daily conversation to examine self-praising behavior in Mandarin interaction practices. It is found that there exist self-praise constraints that moderate Chinese everyday social encounters. In addition, Leech (1983: p. 132) suggested the modesty maxim in his politeness theories, which includes "minimize praise of self" and "maximize dispraise of self". He believed that self-dispraise to some extent can be viewed as a benign behavior and violating the modesty maxim is equal to "committing the social transgression of boasting" (Leech, 1983: p. 136). Brown and Levinson (1987) assumed that in terms of face considerations, elevating others' faces may be seen as downgrading self's face and elevating self's face may be regarded as downgrading others' faces. They considered self-praise as face threat behavior to the listener, for the reason that it reveals that the speaker is self-focused and does not care about the listener's feelings.

Although the assumption in the above-listed literature indicates that self-praise can be regarded as an interactionally social troublesome behavior, different opinions are brought up when it comes to the definition of self-praise. Social psychologists have marked self-praising act as "self-enhancing" or "self-promoting" behavior in which people tend to establish favorable impression on others (Jones \& Pittman, 1982; Leary, 1995). Similarly, linguists have viewed self-praise as "faceelevating" or "face-enhancing" speech act (Dayter, 2014; Matley, 2018). For ex- 
ample, Speer (2012) claimed self-praise as the process of demonstrating people "in a normatively fashion" (e.g., "I am pretty" or "I am clever") (Speer, 2012: p. 52). Dayter (2014: p. 92) proposed that self-praising behavior is a face-elevating act that "involves uttering a positive statement about oneself" which consists of one's achievements, qualities, abilities. These self-praise statements can be positively appreciated by both the speaker and the listener.

In sum, the above-mentioned studies demonstrate that self-praising behavior to some extent may contradict some traditional views on psychology and linguistics. Consequently, self-praise is regarded as face-threatening act or socially risky behavior. However, despite self-praise may involve face-threatening aspect, there are indications that it may carry some positive features in impression management. This may lead to the fact that positive self-praise practices is much under-researched.

\subsection{Self-Praise Strategy Studies}

Previous studies show that self-praise strategy studies are mostly conducted in various situational setting, such as in daily real-life interactional communication (Speer, 2012; Wu, 2011) and online social network community (Dayter, 2014; Tobback, 2019; Rüdiger \& Dayter, 2020; Guo \& Ren, 2020).

Several studies have investigated self-praising speech act in daily conversation. For example, Wu (2011) set up a corpus of China face-to-face daily conversation to examine self-praising behavior in Mandarin interaction practices. She discussed three self-praising practices in Mandarin conversation: "the designedly bipartite turn format", "disclaiming an extreme case situation", and "treating the matter ostensibly as complainable" (Wu, 2011). Within "the bipartite turn format", speakers attempt to alter or bring back the self-praising content without delay after their self-praising speech act. In the pattern of "disclaiming an extreme case situation", speakers mention the relevant extreme case scenario to the matter while consider it as impossible in reality so as to prove that the matter is commendable. As for "treating the matter ostensibly as complainable", it is realized by speakers who delivered their complaint about the matter on purpose which in fact can be regarded as laudable. In a related study, Speer (2012) introduced two self-praise strategies: direct self-praise and praise given by reported third-party compliments and makes a comparison between them. Direct self-praise refers to the process of the speaker directly give self-praising talk by themselves. Direct self-praising techniques consist of "disclaimers" and "qualifications", which involve some interactional characteristics as well as perform to assist the speaker to substantiate their statements. As for praise given by reported third-party compliments, in contrary to direct self-praise, it is assumed that the speakers place the praising comment in the reported compliments from a third party. Speer (2012) claimed that praise given by reported third-party compliments are less troublesome as well as more objective than direct self-praise from the perspective of social interaction. 
In addition to self-praise researches on the daily social interactions, there also exists a number of literatures exploring self-praise on online social network. For example, Dayter (2014) proposed three categories self-praising interaction strategies through investigating ballet students' microblogging posts, namely "explicit self-praise without modification", "explicit self-praise with modification" and "reinterpretation". First, "explicit self-praise without modification" refers to passing the self-praising talk directly, which is closely related to the boasting behaviors. Second, "explicit self-praise with modification" means self-praising acts are modified with various discursive devices. Third, "reinterpretation" is to regarded selfpraise as an indirect speech act. It is found that an overlapping range of selfpraising tactics are employed by the Twitter users and one of the most frequently used strategies is explicit self-praise without modification (Dayter, 2014). Likewise, Rüdiger and Dayter (2020) further developed the self-praise model in their studies of pick-up artists' online community, which is related to two speech act dimensions: direct self-praise and indirect self-praise, explicit self-praise and implicit self-praise. Direct self-praising act can be considered as self-praise for it directly make positive statement about its quality while indirect self-praise is achieved through various ways such as complaining behavior. In a similar vein, an explicit speech act contains self-praise objective embedded in the linguistic forms such as exploiting positive evaluation vocabulary whereas implicit self-praising behavior do not include such linguistic signals.

Besides, Tobback (2019) investigated the self-praise strategies used in the LinkedIn summaries. She not only shed light on a range of direct and indirect selfpraise strategies employed by LinkedIn members to demonstrate their professional qualifications and competent skills, but also specifically explained various kinds of internal pragmatic modifiers used in LinkedIn summaries, which may either have more of less strengthening or softening impact in presenting LinkedIn members' abilities.

Guo and Ren (2020) analyzed the pragmatic tactics performed in the self-praising speech act of Chinese celebrities on microblogging platform Weibo. Following Dayter's (2014) microblogging community study and Tobback's (2019) selfpraising research on LinkedIn, they classified self-praise strategies into three types, namely "explicit self-praise without modification", "modified explicit self-praise" and "implicit self-praise", with each type containing more specific self-praising techniques. Firstly, "explicit self-praise without modification" is defined as the direct application of self-praising words by means of a range of self-presentation ways. Secondly, "modified explicit self-praise" refers to through different techniques in self-praise so as to alter "the degree of the illocutionary force of praising" (Guo \& Ren, 2020: p. 3). Finally, "implicit self-praise" can be employed as an indirect self-praising strategy, which demands the listeners should attempts to decode the post's embedded meaning and infer the speakers' real self-praising purposes. It is assumed that Chinese celebrities are inclined to utilize modified explicit self-praise tactics on Weibo for the reasons that modified explicit self- 
praise tactics may preempt the Chinese celebrities being viewed as boasting as well as it can alleviate the viewers' information processing load (Guo \& Ren, 2020).

Matley (2018) provided some insights into the metalinguistic function of "bragging" Instagram posts as a reference to self-praising speech act. He conducted both qualitative and quantitative approaches on mitigation and aggravation tactics employed in the self-praising Instagram posts. Mitigation strategies involve all the tactics performed to abate the boasting behavior such as denial, apology for boasting and focus transition to others. Aggravation techniques consist of the strategies that may intentionally threat others' face such as insults or added explanations of boasting behaviors in details. It is argued that the hashtags \#brag and \#humblebrag in Instagram posts are utilized "in a balance act of face mitigation and aggravation strategies” (Matley, 2018: p. 30).

As the existing researches demonstrate, self-praise is widely studied in the field of everyday social conversation and online network community. However, despite self-praise frequency in social interaction, self-praising behaviors in organizational setting have been underexplored. More studies are required to comprehend how self-praise strategies performed in diverse organizational discourses and settings. To fill this research gap, the author plans to select Telstra 5 CSRRs from 2016 to 2020 to study the self-praise strategies of CSRRs as well as how CSRRs construct corporate image through self-praise strategies. Hopefully, the author will also be able to draw some implications as to how to improve corporate image through CSRRs.

\section{Methodology}

\subsection{Data Collection}

Established in 1975, Telstra is one of the world's leading telecommunications enterprises and technology service providers. It has consistently published CSRRs since 2003. According to annual reports published by Brand Finance, Telstra has become Australia's number one most valuable brand since 2016. Therefore, Telstra CSRRs from 2016 to 2020 is selected as the research data, which seems to be representative and reasonable. The research data is obtained from Telstra official corporate website (https://www.Telstra.com) and a corpus containing 5 Telstra CSRRs is set up.

In this research, self-praise strategies utilized in Telstra CSRRs will be analyzed. Besides, how these self-praising strategies contributes to Telstra images construction will be explained as well as suggestions on how enterprises construct positive corporate image through CSRRs will be presented.

In this paper, the following research questions will be addressed:

1) What pragmatic strategies of self-praise are employed in Telstra CSRRs from 2016 to 2020 ?

2) What corporate images are presented by these pragmatic strategies of selfpraise in Telstra CSRRs? 
In this study, quantitative analysis and qualitative analysis are adopted, explaining how self-praising strategies are employed in Telstra CSRRs as well as how these tactics help Telstra images construction. Through quantitative analysis, major self-praising strategies of Telstra CSRRs in self-built corpora will be demonstrated with enough specific data. Besides, through qualitative analysis, the data will be explained in details, exploring the connection between self-praising strategies and corporate image construction in CSRRs. By combing qualitative analysis and quantitative analysis, the results of this study can be more objective and reasonable.

\subsection{Data Analysis}

In this study, the following procedures to locate self-praise strategies in the corpus will be applied. First, all the Telstra CSRRs in the corpus will be observed to identify the parts likely to contain self-praise and coded them by NVivo (Version 12). The result showed in the study is modified and inspected by two authors for several times. Next, the strategies followed similar pattern are classified into same category. After that, in reference to previous self-praise strategies researches (Ren \& Guo, 2020; Tobback, 2019; Dayter, 2014; Speer, 2012), the result of self-praising strategies is named similar to them.

\section{Findings}

This section investigates self-praise strategies used in Telstra CSRRs quantitatively and qualitatively. Through quantitative analysis, the frequencies and percentages of self-praise strategies employed in Telstra CSRRs is demonstrated. In addition, through qualitative analysis, the data will be explained in details with some representative sample cases. Table 1 displays the frequencies and percentages of self-praise strategies utilized in Telstra CSRRs.

As demonstrated in Table 1, the indirect self-praise strategies with its five specific subcategories account for $85.18 \%$, presenting the highest proportion of the distribution of self-praise strategies, which indicates that it is utilized in Telstra CSRRs quite frequently. Contrary to the indirect self-praising strategies, the direct self-praise strategies account for $14.81 \%$ of total self-praise collected examples

Table 1. Distribution of self-praise strategies in telstra CSRRs.

\begin{tabular}{ccc}
\hline Self-praise category & Frequency & Percentage (\%) \\
\hline Direct self-praise strategies & 173 & $\mathbf{1 4 . 8 1}$ \\
Indirect self-praise strategies & 995 & $\mathbf{8 5 . 1 8}$ \\
Transfer of the praise focus & 347 & 29.70 \\
Description of hard-work & 309 & 26.46 \\
Praise from a third party & 286 & 24.47 \\
Comparison between previous and present & 35 & 3.00 \\
Comparison between oneself and others & 18 & 1.54 \\
Total & 1168 & 100
\end{tabular}


in the study, showing that they are less employed than the indirect self-praising strategies.

\subsection{Direct Self-Praise Strategies}

As shown from Table 1, the direct self-praise strategies account for $14.81 \%$ of total self-praise examples. In this study, direct self-praise is defined as speakers' explicit self-praising statement through utilizing positive appraising expressions, which is the closest behavior to bragging (Dayter, 2014). As mentioned in the literature review section, it is generally considered that self-praising speech act is socially risky behavior since it is to some extent regarded as a potentially face threatening behavior for the recipient, which indicates that the speaker is better than the recipient (Brown \& Levinson, 1987). Given that the main intentions of the Telstra CSRRs are not only to report information relevant to their commitment to CSR but also to promote Telstra as a responsible enterprise in the increasingly competitive market. In the context of business setting, Telstra frequently deliver its accomplishments and professional abilities to the public on CSRRs, which attempts to construct its competent corporate image. This category of selfpraise consists of three specific tactics.

The first type can be discovered in the statements in which enterprise tend to openly depict their achievements, skills or expertise:

1) We are proud of the meaningful relationships we maintain with our stakeholders and regularly engage with key stakeholder groups to ensure we understand their expectations of us, and are responsive to their varied interests and concerns.

2) We have approximately 200 procurement specialists who support us with complex high value purchases.

The second type can be found in the description in which enterprises describe their identity.

3) We are well positioned to leverage our brand and reputation, a growing customer base, world-leading networks and cutting-edge technologies to maintain our position as Australia's leading telecommunications provider and, most importantly, to achieve our Purpose to build a connected future so that everyone can thrive.

4) Our investment has also positioned Telstra as a world leader in 5G, the next generation of mobile telecommunications technology.

The third type can be embedded in the utterances in which enterprise utilize superlative phrases to directly praise their projects or contributions.

5) As Australia's largest telecommunications provider and one of the largest consumers of electrical and other energy in the country, it is essential that we identify and manage the risks and harness the opportunities that climate change presents for our business.

6) We are Australia's largest corporate purchaser of electricity from renewable projects connected to the grid under project specific agreements. 
As seen from the example (1), Telstra utilizes evaluative phrases "be proud of" to explicitly praise its efforts in regularly keeping in touch with the stakeholders as well as responding to stakeholders' concerns promptly, which construct it as responsive corporate image. In example (2), Telstra appears to directly mention that it has 200 procurement specialists in the whole enterprise, indicating that it has adequate expert resources to support the company. It also portrays Telstra as a professional telecommunications enterprise. While illustrating its identity in CSRRs, Telstra employs evaluative words to explicitly describe its outstanding accomplishments. As example (3) and (4) display, Telstra positions itself in a direct manner as a leading telecommunication company not only in Australia but also in the world. It also demonstrates that Telstra attaches great importance to technology development and investment, which promote it as a pioneering and innovative enterprise. Both in example (5) and (6), through using superlatives, Telstra claims it as Australia's largest telecommunications provider as well as the largest corporate purchaser of electricity from renewable projects in Australia, which compliments its contribution directly. Moreover, it also depicts Telstra as a highly influential telecommunications enterprise in Australia.

\subsection{Indirect Self-Praise Strategies}

As observed from Table 1, the indirect self-praise strategies account for $85.18 \%$ of total self-praise examples. In this study, indirect self-praise, in contrary to direct self-praise, refers to utterances in which speakers do not explicitly represent positive-disclosure on their achievements, abilities and identity. However, the indirect self-praise are also employed to present a positive image to the public. In the following, with reference to the classification on self-praise of Dayter (2014) and Tobback (2019), five discursive designs that Telstra utilize to implicitly praise itself will be explained: transfer of the praise focus, description of hard-work, praise from a third party, comparison between previous and present, comparison between oneself and others.

\subsubsection{Transfer of the Praise Focus}

The transfer of the praise focus means other-oriented praise, assigning the credit to other persons or events that is closely related to the enterprise. The speaker intends to shape a favorable image by altering the praise focus. This tactic accounts for $29.70 \%$ of all the collected data, which is the most frequently utilized strategy in Telstra CSRRs. It seems to be a more careful alternative than direct self-praise strategies since it appears to compliment others, which to some extent poses fewer threats to the recipient's face. The transfer of the praise focus aims to indirectly represent self-praise and alleviate the degree of self-praising behavior.

1) Telstra's products and services play a central role in the daily lives of millions of people, and technologies such as ultrafast 5G mobile, artificial intelligence, software-defined networking, and the Internet of Things (IoT) are transforming markets and redefining the future of work.

2) Our people also identified a range of impediments that were getting in the 
way of working effectively serving our customers and making their jobs harder than they needed to be.

As seen from the example (7), Telstra praises its products and services on the surface level by listing its transformative technology with the aim of implicitly highlighting Telstra essential role performed in the people's daily lives. Not only does Telstra demonstrating its development on products and services to the public, but it also compliments the work it invested and conducted. Through this strategy, Telstra builds a caring corporate image. Similarly, the example (2) depicts that Telstra gives credit to its employee feedbacks, namely, recognition of a range of work obstacles, indicating that Telstra closely interacts with its employees, listens to their needs and acts on their feedback, which also shows that Telstra is enterprise that value employees' interest.

\subsubsection{Praise from a Third Party}

The praise from a third party refers to praising oneself through delivering a third party's praising statement, which implicitly functions as self-praise. The strategy "praise from a third party" accounts for $24.47 \%$ of all the collected data. This strategy aims to confirm the speaker's contributions and performance in a more reasonable manner. Through utilizing such strategy, it is assumed that it would be fewer face-threatening behaviors from self-praise since the speaker does not directly make positive assessment on its own (Tobback, 2019).

1) And our people have told us through their feedback they are proud to work for Telstra, as we have rolled out a range of initiatives to help them, our customers and communities through these difficult times.

2) "This additional funding and support from the Telstra Foundation will allow the deaf community the opportunity to share our language, Auslan, and culture through technology. The financial and expert support from Telstra and Academy Xi will be invaluable, just as it has been throughout the Tech4Good Challenge process. As a non-profit, it's unlikely that Expression Australia would be able to self-fund a project of this magnitude and we look forward to the impact this will have," says Expression Australia Manager Maxine Buxton.

In example (9), Telstra claims nothing positive about itself directly but place an emphasis on employees' satisfied feedback about Telstra, which to some degree increase the neutrality of the content. Not only does Telstra employees' feedback authenticate what Telstra have contributed to others, but also praise Telstra in an indirect manner. At the same time, as seen from example (10), through the utterance of Expression Australia Manager, the information of Telstra providing support and funding to the non-profit organization is delivered to the public. By giving others' compliments on Telstra CSRRs, the real intention of implicitly praise Telstra is achieved. Those two examples portray Telstra as an enterprise concerned about employees as well as society interest.

\subsubsection{Description of Hard-Work}

The description of hard-work is defined as the process in which speakers dem- 
onstrate their efforts in achieving their goals. Through this technique, the speakers attempt to illustrate the hard-working process such as spending an amount of time and energy on the tasks or the investment on the ongoing projects, which in turn make an indirect compliment on themselves. The strategy "description of hard-work" accounts for $24.46 \%$ of all the collected data, which is comparatively high in the distribution of self-praise strategies on Telstra CSRRs. This strategy is similar to other indirect strategies, which do not overtly praise one's accomplishments or abilities. Nevertheless, it attaches great importance to the hard-working process.

1) During COVID-19, our actions were many and varied: they included putting job reductions on hold, providing extra paid leave for Telstra employees and casuals, bringing forward $\$ 500$ million in capital expenditure to calendar year 2020, to provide the economy with much needed investment, creating relief programs for consumer and small business customers, providing temporary unlimited home broadband data allowances and offering free additional mobile data.

2) Along with helping 2.6 million people to stay connected during the COVID19 pandemic, we provided assistance to around 900,000 vulnerable customers and enabled 23,000 people to receive digital capabilities training through our Everyone Connected programs.

Both in example (11) and (12), Telstra is describing what it has done for consumers, employees and society during the COVID-19 in details. More specifically, this information, containing precise projects and exact numbers of its contribution, to some extent further verifies the efforts it made. This indirect selfpraise strategy is realized by demonstrating Telstra's hard-work in solving people's concerns, indicating that it is a responsible enterprise.

\subsubsection{Comparison between Previous and Present}

The comparison between previous and present happens when the speakers make a comparison between past conditions and current conditions. What is noteworthy is that the outcomes of the comparison are often showing that the present conditions are better than the past conditions, therefore the functions of indirect self-praise can be performed. The strategy "comparison between previous and present" accounts for $3 \%$ of all the collected data, suggesting that it occurred infrequently in the distribution of self-praise strategies on Telstra CSRRs.

1) This year, as Australians have adapted to learning, working and spending more time at home, our customers have become more reliant than ever before on the breadth, speed and reliability of our network.

2) Our brand is also performing strongly, with more Australians than ever telling us it's one they feel connected to.

In example (12), it is assumed that Telstra is becoming more reliable to its customers. Through employing comparatives ("have become more reliant than ever before") to compare its previous state and present state, indicating its products and services are verified by consumers. The aim of self-praise is achieved. Likewise, as seen from example (13), it also uses comparatives ("more Australi- 
ans than ever") to note that Telstra is gaining more customers' trust than before, which indirectly praises itself. These two examples also show that Telstra is a favorable company by customers.

\subsubsection{Comparison between Oneself and Others}

The comparison between oneself and others occurs when the speakers make a comparison between itself and others. Through this strategy, the strengths of the speakers will be revealed and thus the intention of self-praise will be achieved indirectly. The strategy 'comparison between oneself and others' accounts for $1.54 \%$ of all the collected data, indicating that it is the least frequently used selfpraise strategy in Telstra CSRRs.

1) Our mobile footprint stretches across more than 2.5 million square kilometres, vastly more than any other mobile network in Australia, reaching 99.5 per cent of the Australian population.

2) Of the 1000 towers erected under the Federal Government's Blackspot program, 800 have been erected by Telstra, four times more than the rest of the industry combined.

As seen from the example (14), Telstra mentions that it has more mobile footprint stretches than other Australian mobile network companies, showing that its products and services has covered the majority areas of Australia. In this case, self-praise is performed by making a comparison about ability between Telstra and other mobile network enterprises in Australia. Likewise, in example (15), Telstra demonstrates that it has built 800 towers, which is four times more than the remaining industry combined. Through delivering this fact to the public on CSRRs, the indirect self-praising speech act is realized. These examples exhibit that Telstra is a responsible enterprise.

It seems that the strategy of comparison between previous and present is similar to the tactic of comparison between oneself and others. Although these two strategies contain the process of comparison, the comparison object is different. The strategy of comparison between previous and present mainly focus on the previous conditions and present conditions of the same subject, while the tactic of comparison between oneself and others predominantly compare the object and other objects alike.

\section{Discussion}

This study explores self-praise strategies utilized in Telstra CSRRs from 2016 to 2020 with a view of how these self-praising strategies contribute to Telstra images construction. It is assumed that both direct self-praising strategies and indirect self-praising strategies were employed in the Telstra CSRRs, with each category containing more specific self-praising techniques. As the above investigation indicates, the indirect self-praise strategies contain transfer of the praise focus, description of hard-work, praise from a third party, comparison between previous and present, comparison between oneself and others, which accounts for $85.18 \%$ of all the self-praising examples collected in Telstra CSRRs. It indi- 
cates that the indirect self-praise strategies represent the highest proportion of the distribution of self-praise strategies, suggesting that it is employed in Telstra CSRRs quite frequently. In contrast, the direct self-praise strategies accounts for $14.81 \%$ of total self-praise collected examples in the study, showing that it is less deployed than the indirect self-praising strategies. In other words, when Telstra praise itself on its annual published CSRRs, it tends to utilize indirect self-praise strategies rather than direct self-praise strategies.

The preference of indirect self-praise strategies on Telstra CSRRs may be due to two reasons. On one hand, unlike the daily social interaction or online social networking posts, the popularity of indirect self-praise strategies on Telstra CSRRs appears to be genre-specific. As noted in the previous section, CSRRs are always considered as an enterprise commitment to CSR goals, an access to provide information about enterprise CSR efforts and a tactical presentation of enterprise initiatives (Danuta de Grosbois, 2012), which are utilized for various purposes, such asa tool for disclosing CSR information (Baraibar-Diez \& LunaSotorrío, 2018) as wellas an instrument for corporate image construction (Bernard, 2020). Hence, it is expected that enterprise predominantly provide its CSR information on CSRRs while at the same time present its favorable corporate image in an indirect manner. In addition, Self-praise aims to present positive self-disclosure. In the case of Telstra CSRRs, the indirect self-praise strategies, according to "facts and figures" (Tobback, 2019), appears to be exhibit Telstra in a more objective and reasonable way, which would also construct Telstra a positive corporate image to the public. On the other hand, it is assumed that indirect self-praising strategies may produce fewer face-threatening behaviors from selfpraise than direct self-praising speech act and to some extent preempt the boasting behaviors (Brown \& Levinson, 1987).

Concerning the corporate image that Telstra CSRRs revealed, the present study finds that through direct self-praise strategies and indirect self-praise strategies, the corporate image of Telstra displays considerable variation. From the perspective of direct self-praise strategies, Telstra CSRRs construct Telstra as a responsive, pioneering and highly influential company in Australia. In terms of indirect self-praise strategies, Telstra CSRRs depicts Telstra as a caring, concerned about interest of society and employees, responsible enterprise. The variation may attribute to the differences between direct self-praise and indirect self-praise. Direct self-praise, as the closest speech act to bragging (Dayter, 2014), is speakers' explicit self-praising statement through utilizing positive appraising expressions. It is assumed that it may pose the direct threat to the recipient's face, indicating that the speaker is better than the recipient (Brown \& Levinson, 1987). Therefore, through direct self-praise strategies, Telstra CSRRs appears to praise Telstra directly towards its strengths, indicating that it is better than others. In addition, indirect self-praise refers to utterances in which speakers do not explicitly represent positive-disclosure on their achievements, abilities and identity. It is believed that indirect self-praise may pose fewer threats to the hearer's face 
and may be more objectively to exhibit self-image. Hence, through direct self-praise strategies, Telstra CSRRs seems to praise Telstra as others-oriented company, suggesting that it is always concerned about others' interest.

\section{Conclusion}

This study investigates self-praise strategies utilized in Telstra CSRRs from 2016 to 2020 with a view of how these self-praising strategies contribute to Telstra images construction. It is assumed that both direct self-praising strategies and indirect self-praising strategies were employed in the Telstra CSRRs, with each category containing more specific self-praising techniques. As the above investigation indicates, the indirect self-praise strategies include transfer of the praise focus, description of hard-work, praise from a third party, comparison between previous and present, comparison between oneself and others, which account for $85.18 \%$ of all the self-praising examples collected in Telstra CSRRs, suggesting that they are employed in Telstra CSRRs quite frequently. In contrast, the direct self-praise strategies account for $14.81 \%$ of total self-praise collected examples in the study, showing that they are less deployed than the indirect self-praising strategies. In addition, through direct self-praise strategies, Telstra CSRRs construct Telstra as a responsive, pioneering and highly influential company in Australia while Telstra CSRRs depict Telstra as caring, concerned about interest of society and employees, responsible enterprise via indirect self-praise strategies.

As the previous researches demonstrate, self-praise is widely studied in the field of everyday social conversation and online network community. Therefore, the present study provides some useful insights into the existing studies about self-praise in organizational settings. Besides, the previous studies of CSRRs mainly focus on CSRRs' functions. Hence, the present study also contributes to the studies of corporate image exhibited in CSRRs.

Finally, it is noteworthy that there exist some limitations in the present study. First, the present study is conducted on the data from Telstra CSRRs, indicating that the collected data may be limited. Accordingly, this study can be extended by means of building a larger corpus. Besides, more researches on self-praise strategies among various CSRRs are encouraged to study the specific as well as universal features of self-praise strategies employed in CSRRs. Second, the present study is limited to general self-praise strategies utilized in CSRRs while it does not analyze the linguistic upgrading or downgrading devices (Tobback, 2019) in the self-praise strategies of CSRRs and the functions of self-praise strategies of CSRRs (Matley, 2018). Therefore, further researches can be conducted through these suggested perspectives.

\section{Conflicts of Interest}

The authors declare no conflicts of interest regarding the publication of this paper.

\section{References}

Baraibar-Diez, E. P., \& Luna-Sotorrio, L. (2018). The Mediating Effect of Transparency in 
the Relationship between Corporate Social Responsibility and Corporate Reputation.

Bernard, T. (2020). Corporate Social Responsibility in Postcolonial Contexts: A Critical Analysis of the Representational Features of South African Corporate Social Responsibility Reports. Critical Discourse Studies, 1-18. https://doi.org/10.1080/17405904.2020.1798797

Brown, P., \& Levinson, S. C. (1987). Politeness: Some Universals in Language Usage (Vol. 4). Cambridge University Press. https://doi.org/10.1017/CBO9780511813085

Brown, T. J., Dacin, P. A., Pratt, M. G., \& Whetten, D. A. (2006). Identity, Intended Image, Construed Image, and Reputation: An Interdisciplinary Framework and Suggested Terminology. Journal of the Academy of Marketing Science, 34, 99-106. https://doi.org/10.1177/0092070305284969

Dayter, D. (2014). Self-Praise in Microblogging. Journal of Pragmatics, 61, 91-102. https://doi.org/10.1016/j.pragma.2013.11.021

Dayter, D. (2021). Dealing with Interactionally Risky Speech Acts in Simultaneous Interpreting: The Case of Self-Praise. Journal of Pragmatics, 174, 28-42.

https://doi.org/10.1016/j.pragma.2020.12.010

De Grosbois, D. (2012). Corporate Social Responsibility Reporting by the Global Hotel Industry: Commitment, Initiatives and Performance. International Journal of Hospitality Management, 31, 896-905. https://doi.org/10.1016/j.ijhm.2011.10.008

Ditlev-Simonsen, C. D. (2010). From Corporate Social Responsibility Awareness to Action? Social Responsibility Journal, 6, 452-468. https://doi.org/10.1108/17471111011064807

Guo, Y., \& Ren, W. (2020). Managing Image: The Self-Praise of Celebrities on Social Media. Discourse, Context \& Media, 38, Article ID: 100433. https://doi.org/10.1016/j.dcm.2020.100433

Jones, E. E., \& Pittman, T. S. (1982). Toward a General Theory of Strategic Self-Presentation. Psychological Perspectives on the Self, 1, 231-262.

Juholin, E. (2004). For Business or the Good of All? A Finnish Approach to Corporate Social Responsibility. Corporate Governance: The International Journal of Business in Society, 4, 20-31.

Leary, M. R. (1995). Self-Presentation: Impression Management and Interpersonal Behavior.

Lee, M. D. P. (2008). A Review of the Theories of Corporate Social Responsibility: Its Evolutionary Path and the Road Ahead. International Journal of Management Reviews, 10, 53 73. https://doi.org/10.1111/j.1468-2370.2007.00226.x

Leech, G. (1983). Principles of Pragmatics. Longman.

Matley, D. (2018). “This Is NOT a\# Humblebrag, This Is Just a\# Brag”: The Pragmatics of Self-Praise, Hashtags and Politeness in Instagram Posts. Discourse, Context \& Media, 22, 30-38. https://doi.org/10.1016/j.dcm.2017.07.007

Pang, A., Lwin, M. O., Ng, C. S. M., Ong, Y. K., Chau, S. R. W. C., \& Yeow, K. P. S. (2018). Utilization of CSR to Build Organizations' Corporate Image in Asia: Need for an Integrative Approach. Asian Journal of Communication, 28, 335-359. https://doi.org/10.1080/01292986.2017.1420207

Pomerantz, A. (1978). Compliment Responses: Notes on the Co-Operation of Multiple Constraints. In Studies in the Organization of Conversational Interaction (pp. 79-112). Academic Press. https://doi.org/10.1016/B978-0-12-623550-0.50010-0

Ren, W., \& Guo, Y. (2020). Self-Praise on Chinese Social Networking Sites. Journal of Pragmatics, 169, 179-189. https://doi.org/10.1016/j.pragma.2020.09.009 
Rüdiger, S., \& Dayter, D. (2020). Manbragging Online: Self-Praise on Pick-Up Artists' Forums. Journal of Pragmatics, 161, 16-27.

https://doi.org/10.1016/j.pragma.2020.02.012

Speer, S. A. (2012). The Interactional Organization of Self-Praise: Epistemics, Preference Organization, and Implications for Identity Research. Social Psychology Quarterly, 75, 52-79. https://doi.org/10.1177/0190272511432939

Tice, D. M., Butler, J. L., Muraven, M. B., \& Stillwell, A. M. (1995). When Modesty Prevails: Differential Favorability of Self-Presentation to Friends and Strangers. Journal of Personality and Social Psychology, 69, 1120. https://doi.org/10.1037/0022-3514.69.6.1120

Tobback, E. (2019). Telling the World How Skilful You Are: Self-Praise Strategies on LinkedIn. Discourse \& Communication, 13, 647-668.

https://doi.org/10.1177/1750481319868854

Wu, R. J. R. (2011). A Conversation Analysis of Self-Praising in Everyday Mandarin Interaction. Journal of Pragmatics, 43, 3152-3176.

https://doi.org/10.1016/j.pragma.2011.05.016 